\title{
HUBUNGAN ANTARA PENGETAHUAN DENGAN SIKAP DALAM MEMBERIKAN IMUNISASI CAMPAK PADA IBU YANG MEMPUNYAI BAYI USIA > 9 - 11 BULAN DI PUSKESMAS SUNGAI RAYA DALAM TAHUN 2019
}

\author{
Alexander ${ }^{1}$, Melyani $^{2}$
}

\author{
Akademi Kebidanan Panca Bhakti Pontianak
}

Email korespondensi: akbidpbpontianak@gmail.com

\begin{abstract}
Abstrak
Indonesia termasuk 10 negara dengan kasus campak terbesar di Dunia pada tahun 2015. Pada tahun 2018 kejadian campak secara global mencapai 48,8\% dan menewaskan 136.000 orang. Data dari Puskesmas Sungai Raya Dalam menunjukkan cakupan imunisasi campak sebesar 76,07\%, hal ini belum mencapai target nasional maupun di provinsi. Tujuan penelitian ini untuk mengetahui apakah ada hubungan antara pengetahuan dengan sikap dalam memberikan imunisasi campak pada ibu yang mempunyai bayi usia > 9 - 11 bulan di Puskesmas Sungai Raya Dalam tahun 2019. Jenis penelitian yang digunakan adalah penelitian deskriptif korelasi dengan pendekatan cross sectional. Besar sampel sebanyak 45 responden diuji menggunakan Chi Square. Hasil penelitian adalah sebagian dari responden yang berpengetahuan baik dengan sikap mendukung $(35,5 \%)$, sangat sedikit dari responden yang berpengetahuan kurang dengan sikap tidak mendukung (2,2\%). Didapatkan dari hasil $\mathrm{x}^{2}=11>\mathrm{x}$ tabel $=5,99$, maka Ha di terima dan Ho di tolak. Ada hubungan antara pengetahuan dengan sikap dalam memberikan imunisasi campak pada ibu yang mempunyai bayi usia > $9-11$ bulan di Puskesmas Sungai Raya Dalam tahun 2019. Kesimpulan dari hasil penelitian ini adalah ada hubungan antara pengetahuan dengan sikap dalam memberikan imunisasi campak pada ibu yang mempunyai bayi usia $>9-11$ bulan di Puskesmas Sungai Raya Dalam tahun 2019.
\end{abstract}

Kata Kunci: Pengetahuan, Sikap, Imunisasi Campak

\begin{abstract}
Indonesia was among the 10 countries with the largest cases of measles in the World in 2015. In 2018 the incidence of measles globally reached $48.8 \%$ and killed 136,000 people. Data from the Sungai Raya Community Health Center shows measles immunization coverage of $76.07 \%$, which has not yet reached the national or provincial targets. The purpose of this study was to determine whether there is a relationship between knowledge and attitudes in providing measles immunization to mothers who have infants aged $>9$ - 11 months at Sungai Raya Community Health Center in 2019. The type of research used is descriptive correlation research with cross sectional approach. Large sample of 45 respondents were tested using Chi Square. The results of the study were some of the respondents who were well-informed with supportive attitudes $(35.5 \%)$, very few of respondents who lacked knowledge with an unsupportive attitude (2.2\%). Obtained from the results of $\mathrm{x} 2=11>\mathrm{x}$ table $=5.99$, then Ha is accepted and $\mathrm{Ho}$ is rejected. There is a relationship between knowledge and attitude in giving measles immunization to mothers who have babies > 9 - 11 months old at Sungai Raya Community Health Center. In 2019, the conclusion of this research is that there is a relationship between knowledge and attitude in giving measles immunization to mothers who have babies age > 9 - 11 months at the Sungai Raya Community Health Center in 2019.
\end{abstract}

Keywords: Knowledge, attitude, measles immunization

\section{Pendahuluan}

Imunisasi Campak adalah imunisasi

yang dilakukan untuk mencegah penyakit campak (measles dan morbili). Imunisasi campak diberikan pada bayi ketika berusia 9 -

\footnotetext{
${ }^{1}$ Dosen Akademi Kebidanan Panca Bhakti Pontianak

${ }^{2}$ Dosen Akademi Kebidanan Panca Bhakti Pontianak
} 
11 bulan (Saputra, 2014). Penyakit campak pada anak akan menimbulkan komplikasi berat, seperti pneumonia atau radang paru dan ensefasilitis atau radang otak, akibat fatalnya adalah kematian. Sekitar 1 dari 20 penderita campak akan mengalami komplikasi radang paru, dan 1 dari 1.000 penderita akan mengalami radang otak. Komplikasi lainnya adalah infeksi telinga yang berujung tuli. 1 dari 10 penderita berakhir tuli. 1 dari 10 penderita akan diare yang membuat mereka harus dirawat di rumah sakit (Anung, 2018).

Berdasarkan data terbaru United Nations Children's Fund (UNICEF), 98 negara di Dunia melaporkan peningkatan kasus campak di banding tahun 2017. Kasus campak mengalami peningkatan signifikan secara global sebesar 48,8\% pada tahun 2018 dan menewaskan 136.000 orang.

Berdasarkan data World Health Organization (WHO) tahun 2015, Indonesia termasuk 10 negara dengan jumlah kasus campak terbesar di dunia. Kementrian Kesehatan mencatat jumlah kasus campak dan rubella di Indonesia sangat banyak dan cenderung meningkat dalam kurun waktu lima tahun terakhir. Adapun jumlah kasus suspek campak-rubella yang dilaporkan antara 2014 sampai dengan juli 2018 sebanyak 57.056 kasus, dimana 8.964 diantaranya positif campak dan 5.737 positif rubella. Tahun 2014 tercatat ada 12.943 kasus suspek, terdiri dari 2.241 positif campak dan 906 rubella. Jumlah ini bertambah mencapai 15.104 kasus suspek di 2017, dimana 2.949 diantaranya positif campak, dan 1.341 positif rubella. Hingga juli 2018 ini sudah tercatat 2.389 kasus suspek, terdiri dari 383 positif campak dan 732 positif rubella. Lebih dari tiga per empat dari total kasus yang dilaporkan, baik campak $88 \%$ maupun rubella $77 \%$, diderita oleh anak usia dibawah 15 tahun (Kemenkes RI, 2018).

Cakupan imunisasi campak di Kalimantan Barat tahun 2017 sebesar 87,7\%. Cakupan imunisasi campak di Kabupaten Kubu Raya tahun 2017 sebesar 75,7\% meningkat dibandingkan tahun 2016 yaitu sebesar 74,9\%. Dinas kesehatan Kabupaten Kubu Raya tetap berusaha mencapai target sebesar 95\%. Hasil survei yang dilakukan oleh peneliti tahun 2019 di Puskesmas Sungai Raya Dalam jumlah bayi yang mendapatkan imunisasi campak pada tahun 2018 sebanyak 408 bayi dari 536 sasaran bayi dan tidak mendapat imunisasi campak sebanyak 128 bayi. Didapatkan hasil bayi yang mendapatkan imunisasi campak tertinggi didapatkan pada bulan September yaitu 48 anak $(8,95 \%)$. Sedangkan peringkat terendah terdapat di bulan April yaitu sebanyak 28 anak $(5,22 \%)$ dan anak yang tidak mendapat imunisasi tertinggi terdapat pada bulan Oktober yaitu 22 anak (4,10\%). Berdasarkan data dan permasalahan yang ada masih terdapat kejadian penyakit campak dan imunisasi campak yang belum mencapat standar target yang di tetapkan. Terutama di Kabupaten Kubu Raya khususnya di Puskesmas Sungai Raya Dalam cakupan imunisasi campak yang dicapai pada tahun 2018 masih kurang yaitu hanya mencapai $76,07 \%$ sedangkan target yang akan menjadi sasaran adalah $95 \%$. 
Opini masyarakat terhadap imunisasi tergantung pada cara seseorang memahami dan mengartikan penting atau tidaknya imunisasi campak pada balita dan ada ibu yang menyatakan setuju anaknya di imunisasi karena memiliki pengetahuan tentang pentingnya imunisasi dan terdapat juga yang tidak setuju anaknya mendapat imunisasi karena mempunyai pengetahuan yang kurang yakin bahwa vaksin dapat mencegah penyakit dan merasa khawatir terhadap efek samping bahkan ada yang tidak tahu sama sekali tentang penyakit campak.

Ada beberapa penyebab sulitnya pemberian imunisasi campak pada bayi salah satunya yaitu pengetahuan ibu yang masih kurang tentang pentingnya imunisasi campak, ibu tidak sempat membawa bayinya imunisasi ke Puskesmas karena jarak yang jauh, serta ada yang sibuk bekerja. Padahal akibat yang akan terjadi jika bayi tidak mendapatkan imunisasi campak salah satunya yaitu terserangnya penyakit campak yang dapat menimbulkan komplikasi radang paru-paru.

Berdasarkan latar belakang diatas maka penulis tertarik untuk meneliti tentang hubungan pengetahuan dengan sikap dalam memberikan imunisasi campak pada ibu yang mempunyai bayi usia $>9$ bulan -11 bulan di Puskesmas Sungai Raya Dalam.

\section{Metode}

Pada penelitian ini menggunakan metode deskriptif korelasi dengan pendekatan secara cross sectional. Sampel dalam penelitian ini sebanyak 45 ibu yang datang dan memberikan imunisasi campak pada bayi usia $>9-11$ bulan Pengumpulan data menggunakan kuesioner dan observasi, kemudian diolah dan dianalisis menggunakan analisis univariat serta analisis bivariat menggunakan uji chi square.

\section{Hasil dan Pembahasan}

Tabel 1 Distribusi Frekuensi Pengetahuan Ibu Tentang Imunisasi Campak Pada Bayi Usia > 9 - 11 Bulan Di Puskesmas Sungai Raya Dalam Tahun 2019

\begin{tabular}{lccc}
\hline & Pengetahuan Responden & $\mathrm{N}$ & $\%$ \\
\hline Kurang & 6 & 13,33 \\
Cukup & 22 & 48,89 \\
Baik & 17 & 37,78 \\
\hline
\end{tabular}

Sebagian dari responden berpengetahuan cukup dari responden berpengetahuan kurang yaitu 6 yaitu 22 responden $(48,89 \%)$ dan sangat sedikit responden $(13,33 \%)$ tentang imuniasi campak.

Tabel 2 Distribusi Frekuensi Sikap Dalam Memberikan Imunisasi Campak Pada Bayi Usia > 9 - 11 Bulan Di Puskemas Sungai Raya Dalam Tahun 2019

\begin{tabular}{lccc}
\hline & Sikap & $\mathrm{N}$ & $\%$ \\
\hline Tidak Mendukung & & 13 & 28,9 \\
Mendukung & 32 & 71,1 \\
\hline
\end{tabular}

Sikap responden dalam memberikan imunisasi campak pada bayi usia $>9-11$ bulan sebagian 
dari responden yaitu 32 responden $(71,1 \%)$

memiliki sikap mendukung dalam pemberian

imunisasi campak pada usia $>9-11$ bulan.

Tabel 3 Hubungan Antara Pengetahuan Dengan Sikap Dalam Memberikan Imunisasi Campak Pada Ibu Yang Mempunyai Bayi Usia > 9 - 11 Bulan Di Puskesmas Sungai Raya DalamTahun 2019

\begin{tabular}{|c|c|c|c|c|c|c|c|}
\hline \multirow{3}{*}{ Lama Penggunaan KB Suntik } & \multicolumn{4}{|c|}{ Sikap } & \multirow{3}{*}{ Total } & \multirow{3}{*}{$\begin{array}{c}\mathrm{P} . \\
\text { Value }\end{array}$} & \multirow{3}{*}{$\alpha$} \\
\hline & \multicolumn{2}{|c|}{ Mendukung } & \multicolumn{2}{|c|}{$\begin{array}{c}\text { Tidak } \\
\text { Mendukung }\end{array}$} & & & \\
\hline & $\sum$ & $\%$ & $\sum$ & $\%$ & & & \\
\hline Kurang & 1 & 2,2 & 5 & 11,1 & 6 & & \\
\hline Cukup & 11 & 24,4 & 11 & 24,4 & 22 & 0,008 & 0,05 \\
\hline Baik & 1 & 2,2 & 16 & 35,5 & 17 & & \\
\hline
\end{tabular}

Hasil uji statistic didapat nilai $\mathrm{p}$ value $=$ $0,008<\alpha=0,05$ maka dapat di simpulkan ada hubungan yang bermakna antara pengetahuan dengan sikap dalam memberikan imunisasi campak pada ibu yang mempunyai bayi usia > 9 - 11 bulan di Puskesmas Sungai Raya Dalam.

\section{Pengetahuan Responden}

Notoatmodjo (2010), menyataan bahwa pengetahuan seseorang tentang suatu objek mengandung dua aspek yaitu aspek positif dan aspek negatif. Pengetahuan adalah segala sesuatu yang diketahui berkenaan dengan pengetahuan merupakan hasil dari tahu dan ini terjadi setelah orang melakukan penginderaan terhadap suatu objek tertentu.

Dari hasil penelitian banyak responden menjawab salah, terbukti pada pertanyaan tentang pengertian imunisasi, karena kurangnya mendapat informasi yang seiring dengan berkembangnya teknologi menyediakan bermacam-macam media massa sehingga dapat mempengaruhi sikap pengetahuan masyarakat dan pengalaman sebelumnya sehingga pengetahuan ibu tentang imunisasi campak dikategorikan kurang. Dikarenakan kurangnya pengetahuan disebabkan oleh informasi yang tidak jelas, misalnya ibu mendengar isu tentang vaksin campak yang palsu serta tidak halal dan tidak mencari tahu kebenarannya.

Berdasarkan data dan permasalahan yang ada masih terdapat kejadian penyakit campak dan imunisasi campak yang belum mencapai standar target yang ditetapkan. Ada beberapa penyebab sulitnya pemberian imunisasi campak pada bayi salah satu pengetahuan ibu masih ada yang kurang tentang pentingnya imunisasi campak.

\section{Sikap Responden}

Sesuai dengan Notoatmodjo (2010), yang menyatakan sikap adalah respon tertutup seseorang terhadap stimulus atau objek tertentu, yang sudah melibatkan faktor pendapat dan emosi yang bersangkutan.

Sikap responden yang tidak mengetahui imunisasi, manfaat, komplikasi dari penyakit campak dan ketakutan terhadap efek samping yang mungkin bisa terjadi pada anaknya sehingga ibu beranggapan imunisasi dapat membuat anaknya menjadi sakit. Sehingga tidak menutup kemungkinan imunisasi campak jika diabaikan maka cepat atau lambat dapat berakibat fatal sebab imunisasi campak perlu 
didapatkan untuk menghindari penyakit campak yang apabila terjadi dapat menimbulkan komplikasi salah satunya dapat menyebabkan kerusakan otak yang permanen. Jadi diharapkan kepada masyarakat, orang tua khususnya ibu - ibu untuk lebih memiliki rasa ingin tahu terhadap kesehatan anak yaitu dengan mencegah penyakit dengan melengkapi imunisasi dasar atau imunisasi wajib.

Kekeliruan responden dalam mendapatkan imunisasi campak pada bayi usia $>9-11$ bulan terlihat dari jawaban responden yang menjawab pernyataan bahwa imunisasi campak untuk melengkapi imunisasi wajib, banyak ibu yang menjawab tidak tepat tentang imunisasi campak.

Imunisasi campak adalah imunisasi yang dilakukan untuk mencegah penyakit campak (measles dan morbili). Penyakit campak adalah penyakit yang sangat mudah menular dan disebabkan oleh virus campak. Penularan penyakit ini adalah melalui udara atau kontak langsung dengan penderita (Saputra, 2014).

Berdasarkan Jurnal kesehatan dan kebidanan oleh Rosalina, Wijayanti, dan Caturningsih di Akademi Kebidanan Mardi Rahayu Kudus (2016) yang berjudul "Hubungan pengetahuan ibu tentang imunisasi campak dengan kepatuhan pemberian imunisasi campak di BPM Lusy Hemawati Mejobo Kudus" dengan hasil penelitian menunjukan bahwa ibu dengan pengetahuan cukup sejumlah $46,60 \%$ dan kepatuhan rata-rata patuh sejumlah $60 \%$. Berdasarkan hasil uji statistik sperman rho didapatkan $\mathrm{p}=0,001<0,05$ yang bermakna bahwa ada hubungan yang signifikan antara pengetahuan ibu tentang imunisasi dengan kepatuhan pemberian imunisasi campak (Rosalina, Hesti Novia dkk, 2016).

\section{Hubungan Antara Pengetahuan Dengan}

Sikap Dalam Memberikan Imunisasi Campak Pada Ibu Yang Mempunyai Bayi Usia > 9 - 11 Bulan

Manfaat utama pemberian imunisasi adalah menurunkan angka kejadian penyakit, kecacatan, maupun kematian akibat penyakit infeksi yang dapat dicegah dengan imunisasi. Imunisasi tidak hanya memberikan perlindungan pada individu. Tetapi juga memberikan perlindungan pada komunitas, terutama pada penyakit ditularkan melalui manusia. Imunisasi juga bermanfaat untuk mencegah epidemik pada generasi yang akan datang. Selain itu, imunisasi dapat menghemat biaya kesehatan. Dengan menurunnya angka kejadian penyakit, biaya kesehatan yang digunakan untuk mengobati penyakit tersebut pun akan berkurang (Saputa, 2014).

Dalam penentuan sikap yang utuh ini, pengetahuan, pikiran, keyakinan dan emosi memegangi peranan penting. Dalam hal ini sikap ibu balita yang bersikap positif dapat menunjukan cakupan imunisasi campak yang lebih ditinggi pada bayinya dibandingkan ibu balita yang memiliki sikap negatif (Wawan dan Dewi, 2011).

Penelitian ini sejalan dengan penelitian yang dilakukan oleh Fitri Islami Addina (2018) tentang Hubungan Tingkat Pengetahuan Ibu Dengan pemberian Imunisasi Dasar Campak di Kelurahan Balai Gadang Wilayah Kerja Puskesmas Air Dingin Kota Padang didapatkan 
adanya hasil ada hubungan yang bermakna antara kedua variabel dengan nilai $\mathrm{p}$ value sebesar 0,001. Penelitian ini juga sejalan dengan penelitian yang dilakukan oleh Merlinta (2018) yang dimana hasil penelitian disimpulkan bahwa hubungan antara pengetahuan tentang vaksin MR dengan minat keikutsertaan vaksinasi MR.

Berdasarkan data dan permasalahan yang ada imunisasi campak tergantung pada cara seseorang memahami dan mengartikan penting atau tidaknya imunisasi campak pada balita dan ibu yang menyatakan setuju anaknya diimunisasi karena memiliki pengetahuan tentang pentingnya imunisasi dan terdapat juga yang tidak setuju anaknya mendapat imunisasi karena mempunyai pengetahuan yang kurang.

Oleh karena itu, pada responden yang tidak mendukung perlu diberikan konseling tentang imunisasi campak, manfaat dan efek samping serta menjelaskan betapa pentingnya imunisasi campak pada bayi. Karena penyakit campak dapat menimbulkan komplikasi radang otak yang permanen. Selain itu dapat diberikan penyuluhan tentang imunisasi campak di Puskesmas maupun diwilayah Kerja Puskesmas Sungai Raya Dalam.

\section{Kesimpulan}

Ada hubungan yang bermakna antara pengetahuan dengan sikap dalam memberikan imunisasi campak pada ibu yang mempunyai bayi usia $>9-11$ bulan di Puskesmas Sungai Raya Dalam.

\section{Daftar Pustaka}

Addina, Fitri Islami. 2018. Hubungan Tingkat Pengetahuan Ibu Dengan Pemberian Imunisasi Dasar Campak Di Kelurahan Balai Gadang Wilayah Kerja Puskesmas Air Dingin Kota Padang. Diploma Thesis, Universitas Andalas, diakses: 26 Februari 2019, 21.43 WIB

Agus, 2013 dalam attachment pdf. DOC Bab II Tinjauan Pustaka Konsep Dasar Pengetahuan.

https://www.academia.edu, diakses 3 April 2019, 15.56 WIB

Anung. 2018. Kasus Campak Meningkat 5 Tahun Terakhir.

https://www.beritasatu.com, diakses : 3 Maret 2019, 20.35 WIB

Arikunto, Suharsimi. 2010. Prosedur Penelitian Suatu Pendekatan Praktik. Jakarta: Rineka Cipta.

Azwar, 2013 dalam attachment pdf. Bab II Tinjauan Pustaka. Digilib.unila.ac.id, diakses 14 April 2019, 21.16 WIB

Cahyono, J.B. Suharjo B dkk. 2010. Vaksinasi Cara Ampuh Cegah Penyakit Infeksi. Yogyakarta: Penerbit Kanisius

Departemen Kesehatan. 2018. Profil Kesehatan Indonesia Tahun 2017 - Kementrian Kesehatan. www.depkes.go.id, diaksen : 3 maret 2019, 23.16 WIB

Dinas Kesehatan. 2018. Profil Kesehatan Kabupaten Kubu Raya.http://dinkes.kalbarprov.go.id, diakses 3 Maret 2019, 22.50 WIB

Dinas Kesehatan. 2018. Profil Kesehatan Provinsi Kalimantan Barat Tahun 2017. http://dinkes.kalbarprov.go.id, diakses: 3 Maret 2019, 23.54 WIB

Fitriani, Sinta. 2011. Promosi Kesehatan. Yogyakarta: Graha Ilmu

Hendriani, Fitria. 2015. Hubungan Antara Pengetahuan Dengan Sikap Ibu Melakukan Imunisasi Dasar Pada Bayi Usia Lebih Dari 9 Bulan Sampai Kurang Dari 12 Bulan Diwilayah Kerja Puskesmas Sungai Durian Tahun 2015. Karya Tulis Ilmiah. Akademi Kebidanan 
Panca Bhakti Pontianak (tidak dipublikasikan).

Hidayat, Aziz Alimul. 2014. Metode Penelitian Kebidanan dan Teknik Analisis Data. Jakarta: Salemba Medika.

Kemenkes RI. 2018. Kasus Campak Meningkat 5 Tahun Terakhir. https://www.beritasatu.com, diakses 3 Maret 2019. 21.59 WIB

Marimbi, Hanum. 2010. Tumbuh Kembang, Status Gizi,dan Imunisasi Dasar Pada Balita. Yoyakarta : Nuha Medika.

Masriroh, Siti. 2016. Keperawatan Pediatrik. Yogyakarta: Penerbit Kyta.

Maulana, Heri. D. J. 2013. Promosi Kesehatan. Jakarta: Buku Kedokteran EGC

Merlinta. 2018. Hubungan Pengetahuan Tentang Vaksin MR (Measles Rubella) Dan Pendidikan Ibu Terhadap Minat Keikutsertaan Vaksinasi MR Di Puskesmas Kartasura. Skripsi. Universitas Muhammadiyah Surakarta, diakses: 26 Februari 2019, 22.55 WIB

Notoatmodjo, Soekidjo. 2010. Promosi Kesehatan Teori \& Aplikasi. Jakarta: Rineka Cipta.

Probawati, 2016 dalam attachment pdf. Bab I Pendahuluan Latar Belakang. http://eprints.ums.ac.id, diakses: 25 Februari 2019, 20.22 WIB

Rahayu, Tri Aulia. 2017. Hubungan Tingkat Pengetahuan Ibu Tentang Imunisasi Campak Booster di Wilayah Kerja Puskesmas Kotagede 1 Yogyakarta. Diakses: 18 Maret 2019, 22.05 WIB

Ranuh, dkk. 2011. Buku Imunisasi di Indonesia. Jakarta: Satgas Imunisasi IDAI

Riyadi, Sarjono \& Sukarmin. 2009. Asuhan Keperawatan Pada Anak. Yogyakarta: Graha Ilmu.

Ronald, H.S. 2011. Pedoman Perawatan Balita Agar Tumbuh Sehat dan Cerdas. Bandung: Nuansa Aulia.

Rosalina, Hesti Novia, dkk. 2016. Hubungan Pengetahuan Ibu Tentang Imunisasi Campak Dengan Kepatuhan Pemberian
Imunisasi Campak di BPM Lusy

Hemawati Mejobo Kudus. Akademi

Kebidanan Mardi Rahayu Kudus. Akbidmr.ac.id, Di akses 18 Maret 2019, 16.22 WIB

Rukiyah, Ai Yeyeh \& Yulianti, Lia. 2010. Asuhan Neonatus Bayi dan Anak Balita. Jakarta: CV. Trans Info Media.

2013. Asuhan Neonatus Bayi dan Anak Balita (3th ed). Jakarta: TIM

Sabrina R, 2016. Bab II Tinjauan Pustaka. Repository.umy.ac.id, diakses 27 Maret 2019, 19.05 WIB

Saputra, Lyndon. 2014. Pengantar Asuhan Neonatus, Bayi, dan Balita. Padang: Binarupa Aksara.

Setiawan, Ari \& Saryono. 2011. Metodologi Penelitian Kebidanan DIII, DIV, S1 dan S2. Yogyakarta: Nuha Medika.

Siswanto, Susila, dkk. 2014. Metodologi Penelitian Kesehatan dan Kedokteran. Yogyakarta: Bursa Ilmu.

Sugiono. 2009. Metode Penelitian Pendidikan Pendekatan Kuantitatif, Kualitatif dan R\&D. Bandung: Alfabeta . 2017. Statistika Untuk Penelitian. Bandung: Alfabeta.

Sumantri, Arif. 2013. Metodologi Penelitian Kesehatan. Jakarta: Kencana Prenada Media Group.

Suryani, Eko \& Badi'ah, Atik. 2018. Asuhan Keperawatan Anak Sehat \& Berkebutuhan Khusus. Yogyakarta: Pustaka Baru Press.

Susila \& Suyanto. 2014. Metodologi Penelitian Epidemiologi. Yogyakarta: Bursa Ilmu.

Timmoria, Iim Fathimah. 2019. Kasus Campak di Dunia meningkat Tajam Selama 2018. https://m.bisnis.com, diakses 5 Maret 2019, 20.05 WIB

Wawan dan Dewi, 2011 dalam Jurnal Yulianti, dkk, 2016. Hubungan Tingkat Pendidikan dan Tingkat Pengetahuan tentang Kesehatan jiwa dengan sikap Masyarakat terhadap Pasien Gangguan Jiwa di RW xx Desa Duwet Kidul, Baturetno, Wonogiri. 
Volume 10 Nomor 1 Tahun 2020

http://ejurnal.akpertikosala, diakses 26

Maret 2016, 23.20 WIB 